doi: $10.15503 /$ jecs20191.219.233

\title{
CULTURAL DIVERSITY IN ENGLISH LANGUAGE LEARNING IN THAILAND AND LATVIA
}

\author{
IEVA RUDZINSKA \\ Department of Management and Communication Science, Latvian Academy \\ of Sport Education, Brīvības gatve 333, Rīga, Latvia \\ E-mail address: ieva.rudzinska@lspa.lv \\ ORCID: https://orcid.org/0000-0001-2345-6789 \\ BURATIN KHAMPIRAT \\ Institute of Social Technology, Suranaree University of Technology \\ Nakhon Ratchasima, Thailand \\ E-mail address: buratink@sut.ac.th \\ ORCID: https://orcid.org/0000-0002-0725-3305
}

\begin{abstract}
Aim. The article examines the characteristics of learning English in students from different cultural backgrounds - Thailand and Latvia.

Methods. The participants were 95 undergraduate sports science students from Thailand (50) and Latvia (45). The Latvian students' parents had a higher level of education than their Thai counterparts. In the study two questionnaires were used: leisure time use of reading and writing activities in English (RWA), and English language learning anxiety scale (ELLAS). RWA included five areas of leisure time use of reading and writing activities: using Internet or e-mail, writing regularly, reading regularly, watching TV or movies, and having a checker; ELLAS consisted of four subscales - Communication Anxiety, Fear of Negative Evaluation, Test Anxiety, and English Classroom anxiety.

Results. Latvian students spent more time watching TV, movies, reading regularly, using Internet or e-mail than Thai students $(p<.01$ and .05). Both Thai and Latvian students experienced moderately elevated communication anxiety, fear of negative evaluation, test anxiety, and English classroom anxiety. However, Thai students had higher anxiety than Latvian students in all aspects of ELLAS (independent samples t-test, $\mathrm{p}<.01$ ).

Conclusions. Thai and Latvian students showed more similarities in their leisure time use of reading and writing activities in English than differences: they often watched movies and TV, but rarely did reading and writing to improve their English. The finding that Latvian students are more confident in all English language learning situations than their Thai counterparts might result from the fact that in Latvia English is more widespread than in Thailand.

Key words: English language learning anxiety scale (ELLAS), leisure time use of reading and writing activities in English (RWA), undergraduate sport science students, Latvia, Thailand, cultural diversity.
\end{abstract}




\section{INTRODUCTION}

The aim of the research is to find out the differences in foreign language 1 learning and assessment in students from different cultural backgrounds - Thailand and Latvia. We aim to find out how they prefer to learn foreign languages; in what contexts it happens, including on-line ones; what reading and writing activities they prefer; how they experience foreign language learning anxiety, including test anxiety, impeding their foreign language learning.

In IMD World Competitiveness Yearbook 2014 (IMD, 2014) 60 countries were assessed in English proficiency (TOEFL); Thailand ranked 57th while Latvia - 32nd. Similarly, in language skills, Thailand ranked 51st, while Latvia was 13 th. We were trying to identify what language learning and testing practices, as well as leisure time language learning activities are at the basis of these results.

Undergraduate students have just come from high schools, therefore their language learning habits and language learning and testing anxiety are based on their experience of language learning and testing at their schools and in their leisure time habits. Students language learning habits and anxiety study could help language teachers develop a safer, more anxiety-free learning environment for students during language learning and testing.

\section{REVIEW OF LITERATURE}

Multilingual EU supports language learning mainly because better language skills enable more people to improve their job prospects and better understand people from different cultures (The new European programme for languages, 2014-2020). Since the 1980s authentic learning contexts are considered of crucial importance in successful foreign language learning (Collie, \& Slater, 1995; Lee, 2005; $\mathrm{Wu}, 2013)$ : written communication is acquired as authentic writing to real addressees (Nunan, 1991; Benson et al., 2002) and reading texts are sufficiently long, reflecting different cultural backgrounds (Nunan, 1995; Dominowski, 2002).

However, attitudes to learning languages are different in different cultures. For example, in Palestine, where ER (extensive reading) and other meaning-based pedagogies are not common, a researcher suggests providing translated versions of Arabic literature, and sources of the Islamic culture in addition to universal literature by famous English and American writers (Abu Saleem, 2010).

Collie and Slater (1995), Lee (2005), and Wu (2013) have developed a Literacy questionnaire, focusing on reading and writing done during leisure time, including writing outside class, writing for own interest, writing diary, reading for pleasure, visiting book stores looking for books of interest, reading magazines, watching TV or movies, and having a checker, who could help improve language. Moreover, the authors have also included learning with IT technologies - having regular e-mail exchanges in English with foreign pen friends, 
having e-mail exchanges in English with friends who speak the same language, being interested in reading English on the internet, using English on the phone or social network (such as Line, Facebook), and participating in online English learning activities.

Since the 1990s in the EU special quality systems for language learning have been developed. In line with basic principles of the "White Paper" (White Paper, 1996), Lasnier has developed the Quality Guide (2003) for assuring quality in a language courses in three learning stages - goal setting, learning process and learning outcomes. Common European Framework of Reference for Languages (CEFR) and European Language Portfolio pay particular attention to the individual learner. According to the quality model, developed by one of the authors for a single study course, an integral part of learning process is the assessment of learning outcomes, including testing, quality model subjects - students, teachers, etc. - who are considered complicated systems, comprising cognitive, conative and affective factors (Rudzinska, 2011; Rudzinska, 2013).

One of the manifestations of affective factors is anxiety - a subjective feeling of tension. A consensus has been reached that foreign language anxiety (FLA) is a unique type of anxiety, because foreign language learning has great potential for students to be embarrassed and frustrated; it challenges their self-esteem and sense of identity (Macintyre, 1999).

In certain situations, e.g., when taking a test or speaking in public, anxiety is even more pronounced. According to Horwitz, Horwitz and Cope theory (Horwitz, Horwitz, Cope, 1986), conceptually important aspects of FLA are three anxieties - communication apprehension, fear of negative evaluation, and test anxiety; the authors introduced the Foreign Language Classroom Anxiety Scale (FLCAS).

Numerous empirical studies measuring anxiety in various instructional settings and different cultures, not limited to European ones, were carried out - Sheorey studied anxiety among Indian high school students (Sheorey, 2006); Tóth researched anxiety in Hungarian students (Tóth, 2008).

FLA construct has been tested and refined; several researchers have doubted the necessity to include test anxiety in English language learning anxiety scale (ELLAS). However, Tóth concluded that test anxiety is an important element of the construct of foreign language anxiety (Tóth, 2008). Tran (2012) reviewed Horwitz, Horwitz and Cope's Theory of Foreign Language Anxiety, concluding that FLCAS measures more language skills rather than anxiety levels, and primarily anxiety related to speaking situations.

Up until now research has concentrated on the classroom-based learner. Within contexts, emerging in virtual learning spaces, learners have to deal successfully with the points when they are confused, or uncertain, or when there is a breakdown in learning (White, 2003), likely to evoke additional language anxieties. 


\section{METHOD}

\section{Participants}

The total number of participants in the study were 95 undergraduate students in Sports Science program (SS) from Thailand and Latvia with a mean age of 21.05 years $(S D=1.85)$. Thai respondents were 50 students from a university in Thailand, $50 \%(n=25)$ were male and $48 \%(n=24)$ were female, 1 declined to give his/her gender. Forty-five undergraduate students were at a university in Latvia, $55.56 \%(n=25)$ were male and $44.44 \%(n=20)$ were female.

Regarding other characteristics of Thai students, most Thai participants $(n$ $=44,88 \%)$ were third-year students, $12 \%(n=6)$ studied in the fourth year. Regarding the highest educational attainment of the participants' parents, the Thai participants declared that: (1) 48\% $(n=24)$ of their fathers and 56\% $(n$ $=28)$ of their mothers obtained lower secondary school, $(2) 22 \%(n=11)$ of fathers and $16 \%(n=8)$ of mothers obtained secondary school, (3) $10 \%(n=5)$ of fathers and $8 \%(n=4)$ of mothers obtained vocational education, (4) $14 \%(n$ $=7)$ of fathers and $18 \%(n=9)$ of mothers obtained a Bachelor's degree, and (5) $4 \%(n=2)$ of fathers and no $(0 \%)$ mothers obtained a higher Bachelor's degree. Regarding home location, the Thai participants self-identified living in the village, hamlet or rural area $(n=36,72 \%)$, a small town $(n=6,12 \%)$, and a town or city $(n=8,16 \%)$. Current number of books at home (do not count newspapers/magazines/schoolbooks) were as follows: $0-10$ books $(n=12,24 \%), 11-25$ books $(n=15,30 \%), 26-100$ books $(n=16,32 \%), 101-200$ books $(n=4,8 \%)$, and over 200 books $(n=3,6 \%)$.

On the Latvian students background information, the year of study consisted of the first year $(n=20,44.44 \%)$, second year $(n=24,53.33 \%)$, and fourth year $(n=1,2.22 \%)$. On the highest educational attainment of the participants' parents, the Latvian participants reported as follows: (1) $11.11 \%(n=5)$ of their fathers and $2.22 \%(n=1)$ of their mothers obtained lower secondary school, (2) $15.56 \%(n=7)$ of fathers and $8.89 \%(n=4)$ of mothers obtained secondary school, (3) $17.78 \%(n=8)$ of fathers and $17.78 \%(n=8)$ of mothers obtained vocational education, (4) $37.78 \%(n=17)$ of fathers and $26.67 \%(n=12)$ of mothers obtained a Bachelor's degree, and (5) $15.56 \%(n=7)$ of fathers and $42.22 \%(n=19)$ of mothers obtained a higher Bachelor's degree. Regarding home location, the Latvian participants self-identified living in the village, hamlet or rural area $(n$ $=8,17.78 \%)$, a small town $(n=14,31.11 \%)$, and a town or city $(n=22,48.89 \%)$. Regarding the number of books at home, Latvian participants reported as follows: $0-10$ books $(\mathrm{n}=11,24.44 \%), 11-25$ books $(\mathrm{n}=14,31.11 \%), 26-100$ books ( $\mathrm{n}$ $=14,31.11 \%), 101-200$ books $(\mathrm{n}=3,6.67 \%)$, over 200 books $(\mathrm{n}=2,4.44 \%)$, and those $(\mathrm{n}=1,2.22 \%)$ who chose not to answer.

More detailed information of participant's characteristics is summarized in Table 1.

Table 1 shows that the proportion of Latvian student parents with higher education was higher than that of Thai's respondents. Regarding the home location, most of the Latvian SS students live in the town, while Thai SS stu- 
Journal of Education Culture and Society No. 1_2019

dents live in the rural areas. Considering the number of books at home, both Thai and Latvian participants had similar proportions.

Table 1. Profile of participant characteristics

\begin{tabular}{|c|c|c|c|c|c|c|}
\hline \multirow{2}{*}{ Demographic characteristics } & \multicolumn{2}{|c|}{ Thailand } & \multicolumn{2}{|c|}{ Latvia } & \multicolumn{2}{|c|}{ Total } \\
\hline & $\mathrm{N}$ & $\%$ & $\mathrm{~N}$ & $\%$ & $\mathrm{~N}$ & $\%$ \\
\hline \multicolumn{7}{|l|}{ Gender } \\
\hline - Male & 25 & 50.00 & 25 & 55.56 & 50 & 52.63 \\
\hline - Female & 24 & 48.00 & 20 & 44.44 & 44 & 46.32 \\
\hline - Decline to respond & 1 & 2.00 & - & - & 1 & 1.05 \\
\hline \multicolumn{7}{|l|}{ Age } \\
\hline - $15-19$ years & - & - & 10 & 22.22 & 10 & 10.53 \\
\hline - $20-25$ years & 49 & 98.00 & 33 & 73.33 & 82 & 86.32 \\
\hline - 26 years and over & - & - & 2 & 4.44 & 2 & 2.11 \\
\hline$-\mathrm{N} / \mathrm{A}$ & 1 & 2.00 & - & - & 1 & 1.05 \\
\hline Mean age (SD) & \multicolumn{2}{|c|}{$21.10(0.92)$} & \multicolumn{2}{|c|}{$21(2.51)$} & \multicolumn{2}{|c|}{$21.05(1.85)$} \\
\hline \multicolumn{7}{|l|}{ Year of study } \\
\hline - Year 1 & - & - & 20 & 44.44 & 20 & 21.05 \\
\hline - Year 2 & - & - & 24 & 53.33 & 24 & 25.26 \\
\hline - Year 3 & 44 & 88.00 & - & - & 44 & 46.32 \\
\hline - Year 4 & 6 & 12.00 & 1 & 2.22 & 7 & 7.37 \\
\hline \multicolumn{7}{|l|}{ Father's education } \\
\hline - Lower secondary school & 24 & 48.00 & 5 & 11.11 & 29 & 30.53 \\
\hline - Secondary school & 11 & 22.00 & 7 & 15.56 & 18 & 18.95 \\
\hline - Vocational education & 5 & 10.00 & 8 & 17.78 & 13 & 13.68 \\
\hline - Bachelor's degree & 7 & 14.00 & 17 & 37.78 & 24 & 25.26 \\
\hline - Higher Bachelor's degree & 2 & 4.00 & 7 & 15.56 & 9 & 9.47 \\
\hline$-\mathrm{N} / \mathrm{A}$ & 1 & 2.00 & 1 & 2.22 & 2 & 2.11 \\
\hline \multicolumn{7}{|l|}{ Mother's education } \\
\hline - Lower secondary school & 28 & 56.00 & 1 & 2.22 & 29 & 30.53 \\
\hline - Secondary school & 8 & 16.00 & 4 & 8.89 & 12 & 12.63 \\
\hline - Vocational education & 4 & 8.00 & 8 & 17.78 & 12 & 12.63 \\
\hline - Bachelor's degree & 9 & 18.00 & 12 & 26.67 & 21 & 22.11 \\
\hline - Higher Bachelor's degree & - & - & 19 & 42.22 & 19 & 20.00 \\
\hline$-\quad$ N/A & 1 & 2.00 & 1 & 2.22 & 2 & 2.11 \\
\hline \multicolumn{7}{|l|}{ Home location } \\
\hline $\begin{array}{l}\text { village, hamlet or rural area } \\
(<3,000 \text { people })\end{array}$ & 36 & 72.00 & 8 & 17.78 & 44 & 46.32 \\
\hline $\begin{array}{l}\text { - A small town } \\
(3,000-15,000 \text { people })\end{array}$ & 6 & 12.00 & 14 & 31.11 & 20 & 21.05 \\
\hline - A town or city & 8 & 16.00 & 22 & 48.89 & 30 & 31.58 \\
\hline$-\quad N / A$ & - & - & 1 & 2.22 & 1 & 1.05 \\
\hline \multicolumn{7}{|c|}{ Number of books at home (do not count newspapers/magazines/schoolbooks) } \\
\hline - $0-10$ books & 12 & 24.00 & 11 & 24.44 & 23 & 24.21 \\
\hline - 11-25 books & 15 & 30.00 & 14 & 31.11 & 29 & 30.53 \\
\hline - 26-100 books & 16 & 32.00 & 14 & 31.11 & 30 & 31.58 \\
\hline - $101-200$ books & 4 & 8.00 & 3 & 6.67 & 7 & 7.37 \\
\hline - over 200 books & 3 & 6.00 & 2 & 4.44 & 5 & 5.26 \\
\hline$-\mathrm{N} / \mathrm{A}$ & - & - & 1 & 2.22 & 1 & 1.05 \\
\hline
\end{tabular}




\section{Instruments}

The questionnaire for the study consisted of three parts: (1) characteristics of participants; (2) reading and writing activities (RWA); and (3) English language learning anxiety scale (ELLAS). The details of each type of questionnaire were as follows.

Characteristics of participants. The basic demographic characteristics of participants explored in this study involve: gender, age, year of study in higher education institution, father's education, mother's education, and home location.

Reading and writing activities (RWA). The survey items of RWA were used to assess reading and writing activities in English that participants do during leisure time. RWA consisted of five activities (14 items) namely: using Internet or e-mail, writing regularly, reading regularly, watching TV or movies, and having a checker. This questionnaire was adapted from Wu (2013), Lee (2005), and Collie and Slater (1995).

English language learning anxiety scale (ELLAS). ELLAS (33 items) was a self-evaluation instrument, adapted from the Foreign Language Classroom Anxiety Scale (FLCAS) developed by Horwitz, Horwitz and Cope (1986). ELLAS consisted of four subscales including Communication Anxiety (8 items), Fear of Negative Evaluation (9 items), Test Anxiety (5 items), and English Classroom Anxiety (11 items).

The respondents of this study were required to rate themselves on each of the statements of RWA and ELLAS on the 5-point Likert scale (1-5), 1 of which refers to strongly agree, 2 to agree, 3 to neutral attitude, 4 - to disagree, and 5 - to strongly disagree. The objective was to assess the level of the use of leisure time reading and writing activities which could improve English skills, as well as the degree of English language anxiety in language classrooms, as manifested in negative performance expectancies and social comparisons, psycho-physiological symptoms and avoidance behaviour.

To assess the reliability of the RWA and ELLAS, the internal consistency of the questions of each aspect was evaluated using the standardised Cronbach alpha reliability coefficient $(\alpha)$. The results showed that the Cronbach's a for five aspects of RWA ranged from .53 to .65 (Table 2 and Table 3 ) and for ELLAS ranged from .63 to .85 . It means that $53 \%$ to $85 \%$ of the answers can be consistently reproduced using the instruments.

\section{Procedures}

Thai participants used the Thai version of RWA and ELLAS questionnaires, translated into the Thai language by one of the authors and one expert in English, whereas Latvian participants used the original questionnaire in English. Data collection was conducted by the authors. In Thailand, the paper survey was administered in the study room by getting the instructor's permission, whilst in Latvia a web-based survey was used to collect data. 


\section{The pilot study}

In 2016 we piloted the study with 23 students $(23.71 \%)$ from a Latvian university and 74 students $(74.29 \%)$ from a university of technology in Thailand. Respondents were freshmen and sophomores, representing Sport Science and Medicine. We employed the same instruments and statistical analysis procedures. Our first tentative results are summarized in Table 2.

Table 2 . Reading and writing activities, and causes of language anxiety

\begin{tabular}{lllll}
\hline Activities/ Language Anxiety & Country & $M$ & $S D$ & $t$-Test \\
\hline Reading and Writing Activities & & & & \\
- Using Internet or E-mail & Thailand & 2.38 & 0.69 & -.476 \\
& Latvia & 2.45 & 0.63 & \\
- Writing Regularly & Thailand & 2.08 & 0.89 & -.893 \\
& Latvia & 2.26 & 0.67 & \\
- Reading Regularly & Thailand & 2.66 & 0.94 & .854 \\
- Having a Checker & Latvia & 2.47 & 0.87 & \\
- Watching TV or Movies & Thailand & 2.05 & 1.10 & -.615 \\
\multirow{5}{*}{ Causes of Language Anxiety } & Latvia & 2.22 & 1.17 & \\
- Communication Anxiety & Thailand & 3.41 & 1.05 & -1.659 \\
& Latvia & 3.83 & 1.11 & \\
- Fear of Negative Evaluation & Thailand & 3.09 & 0.72 & 1.961 \\
& Latvia & 2.76 & 0.69 & \\
& Thailand & 2.95 & 0.86 & 1.537 \\
- Test Anxiety & Latvia & 2.63 & 0.92 & \\
& Thailand & 2.64 & 0.79 & -.540 \\
- English Classroom Anxiety & Latvia & 2.74 & 0.71 & \\
& Thailand & 2.63 & 0.61 & .263 \\
& Latvia & 2.59 & 0.64 & \\
\hline
\end{tabular}

Note. ${ }^{*} p<.05 ;{ }^{* *} p<.01$

The results of the pilot study clearly indicated that during leisure time both Thai and Latvian students often watch movies and spend time sitting in front of the TV to practice and improve English skills (Thai: $M=3.41, S D$ $=1.05$; Latvia: $M=3.83, S D=1.11$ ). On the other hand, they rarely time spent time improving English by using Internet or e-mail (Thai: $M=2.38, S D=0.69$; Latvia: $M=2.45, S D=0.63$ ), and writing regularly (Thai: $M=2.08, S D=0.89$; Latvia: $M=2.26, S D=0.67)$. Similarly, it was difficult to have a checker giving great feedback when they speak or write in English (Thai: $M=2.05, S D=1.10$; Latvia: $M=2.22, S D=1.17)$. However, when considering the size of mean score, it can be noted that Latvian students spend more leisure time on improving English speaking and writing than Thai students.

For English language learning anxiety pilot study both Thai and Latvian students, showed that they had experienced anxiety about Communication 
Anxiety (Thai: $M=3.09, S D=0.72$; Latvia: $M=2.76, S D=0.69$ ), Fear of Negative Evaluation (Thai: $M=2.95, S D=0.86$; Latvia: $M=2.63, S D=0.92$ ), Test Anxiety (Thai: $M=2.64, S D=0.79$; Latvia: $M=2.74, S D=0.71$ ), and English Classroom Anxiety (Thai: $M=2.63, S D=0.61$; Latvia: $M=2.59, S D=0.64$ ). This score indicates that their anxiety level is moderately elevated.

In its turn, the results of the independent t-test, comparing the means of the levels of type of English learning during leisure time between students of different cultures, Thai and Latvian, showed that all the significant values are more than 0.05 , indicating there are no statistically significant differences between the two groups on each type of learning questionnaire.

The independent $t$-test for test mean difference of Thai and Latvian students in each of aspects of ELLAS shows that all significant values are more than 0.05 , showing there is no significant difference between Thai and Latvian students in Communication Anxiety, Fear of Negative Evaluation, Test Anxiety and English Classroom Anxiety.

The pilot study showed that medicine students of Thailand and sport science students of Latvia are both likely to enjoy reading and writing in English during their leisure time. However, Latvian students are more likely than Thai students to enjoy and spend more time watching English TV or movies. Furthermore, the present research confirmed that both Thai and Latvian students have the same level of experiencing moderate anxiety in learning English. That could mean that students, whose native language is not English, generally had a feeling of anxiety when learning English, and for the practice of English they prefer watching television or films to reading books, writing and using internet for learning purposes.

According to the findings of the pilot study, although the students come from different cultural backgrounds, the variance of all aspects was not found in Thai and Latvian students. The result might be associated with the fact that the Thai student background is a Medicine Program, since medicine students are usually high achievers in studying.

\section{Data analysis}

The first part of the descriptive statistics was used to explain and summarize the features of the participants and data. Mean $(M)$ was used to describe the level of all aspects, whereas Standard Deviation $(S D)$ - to measure the variability of responses. For the visual presentation of country differences in reading and writing activities RWA and English language learning anxiety scale ELLAS, the means were also plotted in Figure 1 and Figure 2.

The second part, independent samples t-test was performed to test hypotheses with the aim of comparing the mean differences between Thai and Latvian student practice in 5 aspects of RWA, namely, using Internet or e-mail, writing regularly, reading regularly, watching TV or movies, and having a checker, and 4 types of Anxiety of ELLAS, including (1) the English reading and writing activities, (2) Communication Anxiety, (3) Fear of Negative Evaluation, (4) Test Anxiety and (5) English Classroom Anxiety, as well as in their particular items. 
Results. Cultural diversity in RWA

As shown in Figure 1 and Table 2, the results of this study clearly indicated that during leisure time both Thai and Latvian students often watched movies and spent time sitting in front of the TV to practice and improve their English skills (Thai: $M=3.12, S D=1.08$; Latvian: $M=4.02, S D=1.00$ ). However, they rarely spent time on improving English by using Internet or e-mail (Thai: $M=$ 2.34, $S D=0.68$; Latvian: $M=2.70, S D=0.70$ ), reading regularly (Thai: $M=2.13$, $S D=0.61$; Latvian: $M=2.51, S D=0.81$ ), and writing regularly (Thai: $M=2.03$, $S D=0.53$; Latvian: $M=2.25, S D=0.75)$. Similarly, it was difficult to have a checker who would give a great feedback when they spoke or wrote in English (Thai: $M=2.12, S D=0.98$; Latvian: $M=2.11, S D=1.06$ ).

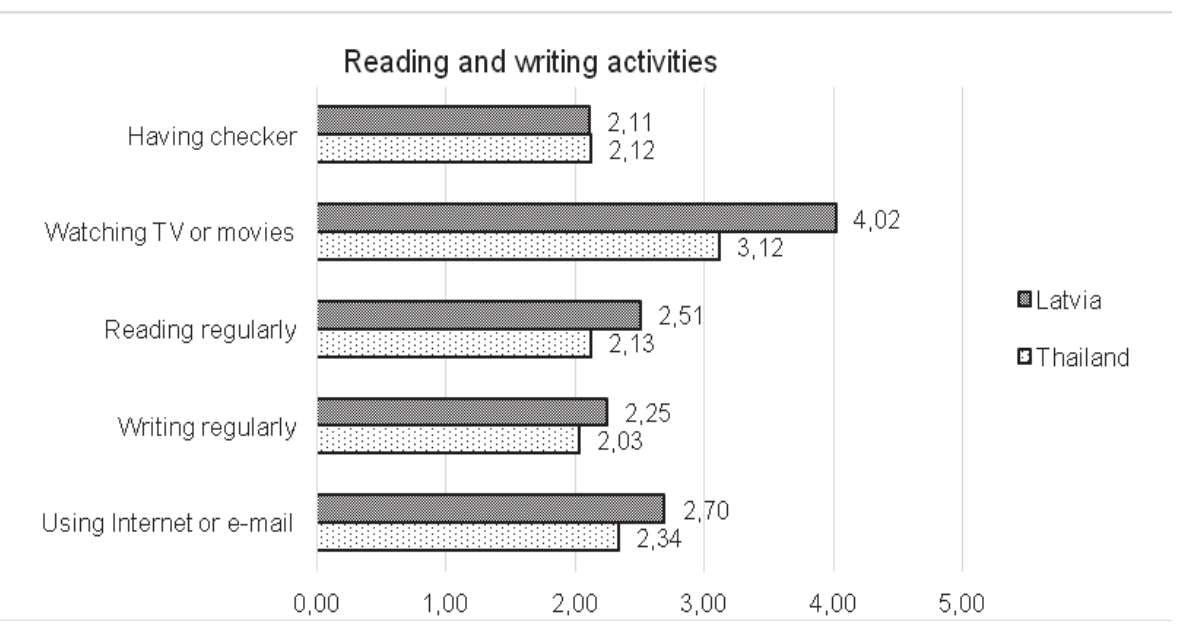

Figure 1. Mean score of RWA for Thai and Latvian students.

Considering the size of mean score, it can be noted that Latvian students spent more leisure time to improve speaking and writing in English than Thai student at the statistically significant level of .01 and .05 on watching TV or movies $(t(94)=4.23, p<.01$, Cohen's $d=0.87)$, reading regularly $(t(94)=2.61$, $p<.01$, Cohen's $d=.53)$, and using Internet or writing e-mails $(t(94)=2.55, p<$ .05 , Cohen's d =.52).

On the other hand, there was no statistically significant difference in the mean scores between the two groups on writing regularly $(t(94)=1.60, p>.05)$ and having a checker $(t(94)=0.05, p>.05)$ (Table 3). 
Table 3. Mean (M), standard deviation (SD), and comparison of mean scores of Reading and Writing activities with independent t-test

\begin{tabular}{|c|c|c|c|c|c|c|}
\hline \multirow[t]{2}{*}{ Activities/Items } & \multirow{2}{*}{$\alpha$} & \multicolumn{2}{|c|}{ Thailand } & \multicolumn{2}{|c|}{ Latvia } & \multirow[t]{2}{*}{ T-test } \\
\hline & & $M$ & $S D$ & $M$ & $S D$ & \\
\hline Using Internet or e-mail & .62 & 2.34 & 0.68 & 2.70 & 0.70 & $-2.55^{*}$ \\
\hline $\begin{array}{l}\text { - I have regular e-mail exchanges in English } \\
\text { with foreign pen pals. }\end{array}$ & & 1.80 & 0.97 & 2.39 & 1.16 & $-2.71^{* *}$ \\
\hline $\begin{array}{l}\text { - I have e-mail exchanges in English } \\
\text { with friends who speak/talk the same } \\
\text { language. }\end{array}$ & & 2.10 & 1.15 & 2.37 & 1.10 & -1.17 \\
\hline $\begin{array}{l}\text { - I am interested in reading English on the } \\
\text { internet. }\end{array}$ & & 2.66 & 1.12 & 2.85 & 1.41 & -0.72 \\
\hline $\begin{array}{l}\text { - I use English on the phone or social } \\
\text { network (such as Line, Facebook). }\end{array}$ & & 3.12 & 1.04 & 4.02 & 1.02 & $-4.27^{* *}$ \\
\hline $\begin{array}{l}\text { - I participate in online English learning } \\
\text { activities. }\end{array}$ & & 2.00 & 0.97 & 1.85 & 1.05 & 0.74 \\
\hline Writing regularly & .53 & 2.03 & 0.53 & 2.25 & 0.75 & -1.60 \\
\hline - I write a diary and/or text in English. & & 1.58 & 0.67 & 1.78 & 0.84 & -1.31 \\
\hline $\begin{array}{l}\text { - I practice English writing for my own } \\
\text { interest. }\end{array}$ & & 2.14 & 0.83 & 2.17 & 1.12 & -0.17 \\
\hline - I speak and write in English outside class. & & 2.38 & 0.78 & 2.78 & 1.03 & $-2.17^{*}$ \\
\hline Reading regularly & .65 & 2.13 & 0.61 & 2.51 & 0.81 & $-2.61^{* *}$ \\
\hline - I read in English for pleasure. & & 2.30 & 0.91 & 2.78 & 1.19 & $-2.24^{*}$ \\
\hline $\begin{array}{l}\text { - I visit the library or check out English } \\
\text { books (for outside reading). }\end{array}$ & & 1.86 & 0.76 & 2.11 & 1.02 & -1.35 \\
\hline $\begin{array}{l}\text { - I visit bookstores looking for English } \\
\text { books I am interested in. }\end{array}$ & & 2.06 & 0.98 & 2.11 & 1.06 & -0.23 \\
\hline - I read English magazines/newspapers. & & 2.28 & 0.78 & 3.02 & 1.31 & $-3.34^{* *}$ \\
\hline Watching TV or movies & a & 3.12 & 1.08 & 4.02 & 1.00 & $-4.23^{* *}$ \\
\hline - I watch English TV/movies. & & 3.12 & 1.08 & 4.02 & 1.00 & $-4.23^{* *}$ \\
\hline Having a checker & a & 2.12 & 0.98 & 2.11 & 1.06 & 0.05 \\
\hline $\begin{array}{l}\text { - I have a checker who gives me great } \\
\text { feedback whenever I speak or write an } \\
\text { English sentence. }\end{array}$ & & 2.12 & 0.98 & 2.11 & 1.06 & 0.05 \\
\hline
\end{tabular}

Note. ${ }^{*} \mathrm{p}<.05,{ }^{* *} \mathrm{p}<.01$ (two-tailed test). Scale scores ranged from 1 to $5 ;{ }^{a}=$ the internal consistency reliability of this aspect could not be calculated, because there is only one item.

\section{Cultural diversity in ELLAS}

The application of ELLAS showed that both Thai and Latvian students (Figure 2 and Table 3 ) had experienced communication anxiety (Thai: $M=3.27$, $S D=0.60$; Latvia: $M=2.70, S D=0.63$ ), fear of negative evaluation (Thai: $M=$ 3.28, $S D=0.65$; Latvia: $M=2.59, S D=0.85$ ), Test Anxiety (Thai: $M=3.12, S D$ $=0.53$; Latvia: $M=2.51, S D=0.78$ ), and English Classroom Anxiety (Thai: $M$ $=3.02, S D=0.59$; Latvia: $M=2.54, S D=0.61$ ). These scores indicate that their anxiety level is moderately elevated. 
The results of independent samples t-test presented in Table 4 indicated that Thai student anxiety in all aspects of ELLAS was higher than that of Latvian students at the statistically significant level of .01, communication anxiety ( $t$ $(93)=4.52, p<.01$, Cohen's $d=0.93)$, fear of negative evaluation $(t(84.20)=$ $4.38, p<.01$, Cohen's d $=0.91)$, test anxiety $(t(78.14)=4.43, p<.01$, Cohen's d $=0.91)$, and English classroom anxiety $(t(93)=3.85, p<.01$, Cohen's d $=0.80)$.

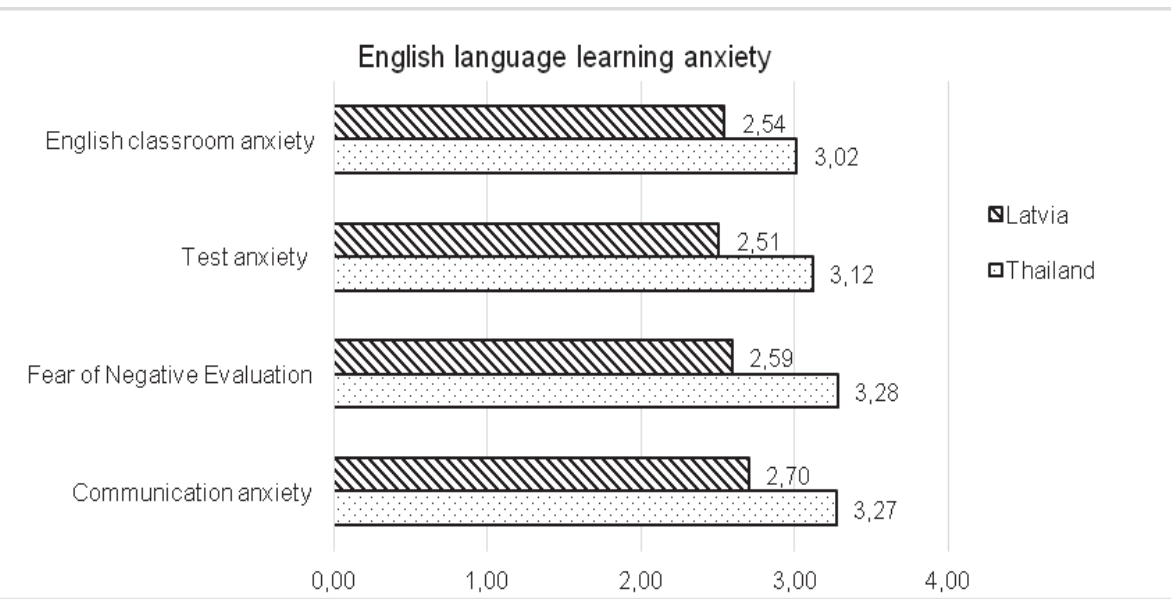

Figure 2. Mean score of ELLAS for Thai and Latvian students.

Table 4. Mean (M), standard deviation (SD), and comparison of mean scores of English language learning anxiety with independent t-test

\begin{tabular}{|c|c|c|c|c|c|c|}
\hline \multirow[t]{2}{*}{ Anxiety/Items } & & \multicolumn{2}{|c|}{ Thailand } & \multicolumn{2}{|c|}{ Latvia } & \multirow[t]{2}{*}{ T-test } \\
\hline & & $M$ & $S D$ & $M$ & $S D$ & \\
\hline Communication anxiety & .73 & 3.27 & 0.60 & 2.70 & 0.63 & $4.53^{* *}$ \\
\hline $\begin{array}{l}\text { - I never feel quite sure of myself when I am } \\
\text { speaking in my English language class. }\end{array}$ & & 3.08 & 2.85 & 1.00 & 1.19 & 1.04 \\
\hline $\begin{array}{l}\text { - I start to panic when I have to speak without } \\
\text { preparation in language class. }\end{array}$ & & 3.77 & 2.39 & 0.99 & 1.32 & $5.69^{* *}$ \\
\hline $\begin{array}{l}\text { - I would not be nervous speaking the English } \\
\text { language with native speakers. (reversed score) }\end{array}$ & & 3.12 & 2.52 & 1.22 & 1.17 & $2.45^{*}$ \\
\hline $\begin{array}{l}\text { - I feel confident when I speak in English } \\
\text { language class. (reversed score) }\end{array}$ & & 3.40 & 2.67 & 0.82 & 1.06 & $3.72 * *$ \\
\hline $\begin{array}{l}\text { - I feel very self-conscious about speaking the } \\
\text { English language in front of other students. }\end{array}$ & & 3.35 & 3.17 & 0.95 & 0.88 & 0.92 \\
\hline $\begin{array}{l}\text { - I get nervous and confused when I am } \\
\text { speaking in my language class. }\end{array}$ & & 3.06 & 2.33 & 0.99 & 1.27 & $3.14^{* *}$ \\
\hline $\begin{array}{l}\text { I get nervous when I don`t understand every } \\
\text { word the language teacher says. }\end{array}$ & & 3.49 & 2.91 & 0.84 & 1.35 & $2.48^{*}$ \\
\hline - I would probably feel comfortable around & & 2.96 & 2.78 & 1.26 & 1.09 & 0.73 \\
\hline
\end{tabular}
native speakers of the English language. (reversed score) 
Fear of Negative Evaluation

- I tremble when I know that I'm going to be called on in language class.

- I keep thinking that the other students are better at languages than I am.

- It embarrasses me to volunteer answers in my language class.

- I get upset when I don't understand what the teacher is correcting.

- I can feel my heart pounding when I'm going to be called on in language class.

- I always feel that the other students speak the English language better than I do.

- Language class moves so quickly I worry about getting left behind.

- I am afraid that the other students will laugh at me when I speak the English language.

- I get nervous when the language teacher asks questions which I haven't prepared in advance.

Test anxiety

- I don't worry about making mistakes in language class. (reversed score)

- I am usually at ease during tests in my language class. (reversed score)

- I worry about the consequences of failing my English language class.

- I am afraid that my language teacher is ready to correct every mistake I make.

- The more I study for a language test, the more confused I get.

English classroom anxiety

- It frightens me when I don't understand what the teacher is saying in the English language.

- It wouldn't bother me at all to take more English language classes. (reversed score)

- During language classes, I find myself thinking about things that have nothing to do with the course.

- I don't understand why some people get so upset over English language classes. (reversed score)

- In language class, I can get so nervous I forget things I know.

- Even if I am well prepared for language class, I feel anxious about it.

- I often feel like not going to my language class.

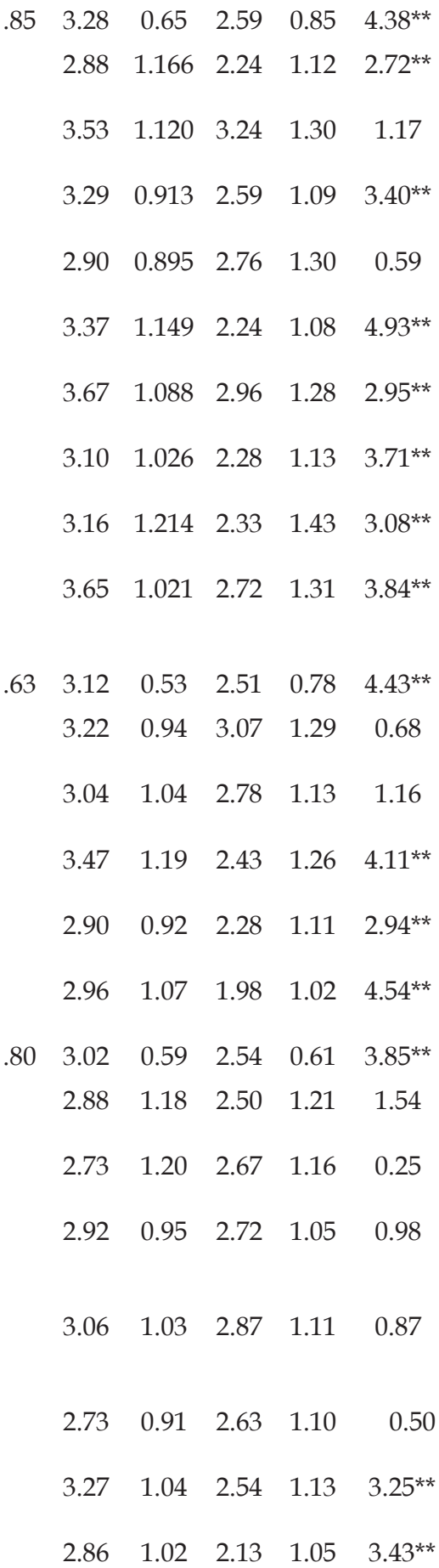


Journal of Education Culture and Society No. 1_2019

- I don't feel pressure to prepare very well for $\begin{array}{lllll}3.06 & 1.16 & 2.70 & 1.14 & 1.55\end{array}$ language class. (reversed score)

- I feel more tense and nervous in my language class than in my other classes.

- When I'm on my way to language class, I feel very sure and relaxed. (reversed score)

- I feel overwhelmed by the number of $3.18 \quad 0.99 \quad 2.13 \quad 1.19 \quad 4.71^{* *}$ rules you have to learn to speak in English language.

Note. ${ }^{*} \mathrm{p}<.05,{ }^{* *} \mathrm{p}<.01$ (two-tailed test). Scale scores ranged from 1 to 5 .

\section{DISCUSSION}

In this section we would like to compare the results of this study with the ones of the pilot study performed a year before.

In this study, investigated cross-cultural differences between the two countries were repeated. The pilot and current study showed that sport students from Thailand and Latvia show more similarities in practising their English than differences. Namely, they are likely to enjoy reading and writing in English during their leisure time.

Furthermore, the present research confirmed that both Thai and Latvia students exhibit the same moderate level of anxiety in learning English, implying that students, who were not native English speakers, generally had a feeling of anxiety in learning a foreign language - in our case, English - and for practicing English they preferred watching television or films to spending time on reading books, writing and using Internet for language learning purposes.

However, Latvian students were found to spend more leisure time on improving speaking and writing in English, on watching TV or movies, reading regularly, and using Internet or writing e-mails than Thai students. On the other hand, there was no statistically significant difference in the mean scores between the two groups on writing regularly and having a checker, who could help to improve their English skills in situ.

The application of ELLAS showed that both Thai and Latvian students had experienced all English Language Learning Anxiety Scale aspects - Communication Anxiety, Fear of Negative Evaluation, Test Anxiety, and English Classroom Anxiety.

The scores indicated that their anxiety level was moderately elevated. The results indicated that Thai student anxiety in all aspects of ELLAS - Fear of Negative Evaluation, Test Anxiety, and English Classroom Anxiety - was higher than that of Latvian students at the statistically significant level. From the background knowledge, we might conclude that for Latvian students practicing English might be easier, because English is more widespread in Latvia than in Thailand. Moreover, this evidence is reflected in the fact that there was no need to translate questionnaires used in the study in the Latvian language, but an effort was taken to translate them into the Thai language. The 
students from Latvia might find learning foreign languages easier due to the fact that more of their parents have higher education than Thai respondents. The results are consistent with the broader literature based on the impact of the cultural differences on learner between Asian and Western countries (e.g., Chao, 2014; Frambach, Driessen, Beh \& van der Vleuten, 2014; Morony, Kleitman, Lee \& Stankov, 2013). It is argued that (Lorencowicz \& Lorencowicz, 2013) geographical conditions, history, and many other factors have strongly varied Asian and European styles. However, Thai students have high anxiety in using English and tend to use English for communication only in the classroom (Pawapatcharaudom, 2007) because they may have lack of confidence or may be concerned about loss of face or bad impression when making mistakes (Ariyanti, 2016; Riasati, 2012). Therefore, they rarely use English language for communication and are facing enormous difficulties in learning English (Chottum, Kunchai \& Khampirat, 2018; Wiriyachitra, 2002).

\section{CONCLUSIONS}

In summary, this study has yielded important insights about cultural diversity in English language learning in Thailand and Latvia. In particular, ELLAS has showed that the level of Thai student anxiety was higher than that of Latvian students. This cross-cultural study provides some essential empirical evidence of how cultural attributes influence the RWA and ELLAS levels. However, the results of the study might imply that learning foreign languages could benefit from more exposure to authentic language through watching TV or movies, reading regularly, and using Internet or writing e-mails. Finally, having better command of foreign language might lower all the aspects of English Language Learning Anxiety - Fear of Negative Evaluation, Test Anxiety, and English Classroom Anxiety.

\section{REFERENCES}

[1] Abu Saleem, L. (2010). Impact of extensive reading on literacy perceptions and on EFL writing quality of English major students at the Islamic University of Gaza (Unpublished Master thesis). Palestine: Islamic University of Gaza.

[2] Ariyanti, A. (2016). Psychological factors affecting EFL students' speaking performance. ASIAN TEFL, 1 (1). DOI: 10.21462/asiantefl.v1i1.14.

[3] Benson, C., Christian, S., Goswami, D., \& Gooch W.H. (eds.). (2002). Writing to Make a Difference: classroom projects for community change. New York, NY: Teacher College Press.

[4] Chao, R. Y. (2014). Pathways to an East Asian higher education area: A comparative analysis of East Asian and European regionalization processes. Higher Education, 68 (4), 559-575. DOI: 10.1007/s10734-014-9728-y.

[5] Collie, J., Slater, S. (1995). True to life elementary teacher's book: English for adult learners. Cambridge, UK: Cambridge University Press.

[6] Chottum, N., Kunchai, J., Khampirat, B. (2018, June). Factors Affecting Willingness to Communicate in English of Thai Co-operative Education Students. In: K. E. Zegwaard, M. Ford (Eds.), Refereed Proceedings of the 3rd International Research Symposium on Cooperative and WorkIntegrated Education: World Association for Cooperative Education (WACE), Stuttgart, Germany, 23-27 June 2018 (pp. 23-29). Hamilton, New Zealand: University of Waikato. 
[7] Dominowski, L. R. (2002). Teaching Undergraduates. London, UK: LEA Publishing.

[8] Frambach, J. M., Driessen, E. W., Beh, P., van der Vleuten, C. P. M. (2014). Quiet or questioning? Students' discussion behaviors in student-centered education across cultures. Studies in Higher Education, 39 (6), 1001-1021. DOI: 10.1080/03075079.2012.754865.

[9] Horwitz, E. K., Horwitz, M. B., Cope, J. (1986). Foreign language classroom anxiety. The Modern Language Journal, 70 (2), 125-132. DOI: 10.2307/327317.

[10] IMD (2014). IMD world competitiveness yearbook 2014. Lausanne, CH: IMD.

[11] Khampirat, B., Rudzinska, I. (2015, September). Learning motivation orientation and learning strategies in Thai and Latvian students. Paper presented at the 2015 European Conference on Educational Research, Budapest, Hungary. Retrieved from http://www.eera-ecer.de/ ecer-programmes/conference/20/.../496.

[12] Lasnier, J. C. (2003). Quality, Version 2003, Retrieved from http://www.quiltnetwork.org, 5.05.2007.

[13] Lee, S. Y. (2005). Facilitating and inhibiting factors in English as a foreign language writing performance: A model testing with structural equation modeling. Language Learning, 55(2), 335-374. DOI: 10.1111/j.0023-8333.2005.00306.x.

[14] Lorencowicz, H., Lorencowicz, E. (2013). Cultural differences and doing business in Asia and Europe - an example of Taiwan and Poland. Roczniki Naukowe Stowarzyszenia Ekonomistów Rolnictwa i Agrobiznesu, 15 (3), 217-223.

[15] Macintyre, P. D. (1999). Language anxiety: A review of the research for language teachers In D. J. Young (Ed.), Affect in foreign language and second language learning: A practical guide to creating a low-anxiety classroom atmosphere (pp. 24-45). Boston, MA: McGraw-Hill.

[16] Morony, S., Kleitman, S., Lee, Y. P., \& Stankov, L. (2013). Predicting achievement: Confidence vs self-efficacy, anxiety, and self-concept in Confucian and European countries. International Journal of Educational Research, 58, 79-96. DOI: j.ijer.2012.11.002

[17] Nunan, D. (1995). Language teaching methodology: A textbook for teachers. New York, NY: Phoenix.

[18] Nunan, D. (1991). The Learner-centered Curriculum: A study in second language teaching. London, UK: Cambridge University Press.

[19] Pawapatcharaudom, R. (2007). An investigation of Thai students' English language problems and their learning strategies in the international program at Mahidol University. (Unpublished Master's thesis). Thailand: King Mongkut's Institute of Technology North.

[20] Riasati, M. J. (2012). EFL learners' perception of factors influencing willingness to speak English in language classrooms: A qualitative study. World Applied Sciences Journal, 17 (10), 1287-1297.

[21] Rudzinska, I. (2013). Use of quality models and indicators for evaluating test quality in an ESP course. Journal of Education Culture and Society, 2, 200-207. DOI: 10.15503/jecs20132-200-207.

[22] Rudzinska, I. (2011). Quality assurance in promoting student professional foreign language competence (Doctoral dissertation). Latvia: University of Latvia. Riga.

[23] Sheorey, R. (2006). Anxiety about English language learning among Indian high school students. In R. Sheorey (Ed.), Learning and teaching English in India (pp. 163-178). New Delphi, IN: Sage Publications.

[24] Tóth, Z. (2008). Foreign language anxiety scale for Hungarian learners of English. WoPaLP, 2, 55-78.

[25] Tran, T. T. T. (2012). A review of Horwitz, Horwitz and Cope's theory of foreign language anxiety and the challenges to the theory. English Language Teaching, 5 (1), 69-75. DOI: 10.5539/ elt.v5n1p69.

[26] Wiriyachitra, A. (2002). English language teaching and learning in Thailand in this decade. Thai TESOL focus, 15 (1), 4-9.

[27] White, C. (2003). Language learning in distance education. Cambridge, UK: Cambridge University Press.

[28] White Paper (1996). Teaching and learning. Towards the learning society, Brussels, Luxembourg, 1996.

[29] Wu, L.-F. (2013). A Study of factors affecting college students' use of ESL vocabulary learning strategies. International Journal of Humanities and Social Science, 3 (19), 202-208. 